\title{
Investigation of argyrophilic nucleolar organizing region
}

\author{
Nisari $\mathrm{M}^{1}$, Eroz $\mathrm{R}^{2}$, Nisari $\mathrm{M}^{3}$, Ertekin $\mathrm{T}^{3}$, Oktay $\mathrm{M}^{4}$, Kavutcu $\mathrm{M}^{1}$ \\ Department of Nutrition and Dietetics, Nuh Naci Yazgan University, Faculty of Health Sciences, Kayseri, Turkey. \\ mnisari@nny.edu.tr
}

\begin{abstract}
BACKGROUND: Ischemia/reperfusion (I/R) injury is a complex event frequently observed in vascular surgery and can cause functional and structural cell damage. Nucleolar-organizing regions (NORs) are sites of the ribosomal genes located on chromosomes and can be stained with silver when they are active. Thus these proteins are named as argyrophilic-NOR (AgNOR)-associated proteins. We aimed to investigate any possible effects of renal I/R injury on the NOR protein synthesis and association between the AgNOR proteins amount and histopathological injuring score.

METHODS: Nine female wistar-albino rats with weight of 200-250g were included into the study. The animals were randomly divided in two groups, a Control Group and an I/R Group. In I/R group, rats were subjected to 45 minutes of renal pedicle occlusion followed by 24 hours of reperfusion. In the control group no drug injections or ischemia reperfusion were performed in animals. Then histopathological injury score, mean AgNOR number and total AgNOR area/nuclear area (TAA/NA) were detected for each rat.

RESULTS: The differences between control and I/R groups were significant for histopathological injury scores $(p$ $=0.016$ ). Also the differences between control group and I/R group were significant for mean AgNOR number $(p=0.000)$ and TAA/NA ratio $(p=0.000)$. Additionally, there was a positive correlation between TAA/NA ratio and histopathological injury score $(r=0.728 ; p=0.026)$ and between mean AgNOR number and histopathological injury score $(r=0.670 ; p=0.048)$.

CONCLUSION: The detection of AgNOR proteins amount may be used as an indicator to obtain information about the cellular behaviour (self-protective mechanism of tubular epithelial cells) against I/R injury and cellular damage levels (Tab. 2, Fig. 4, Ref. 24). Text in PDF www.elis.sk.

KEY WORDS: NOR, AgNORs, ischemia-reperfusion, rDNA.
\end{abstract}

\section{Introduction}

The term of ischemia indicates insufficient blood supply to tissues owing to obstruction of the arterial inflow. Therefore, biomedical researchers and physicians have coped to better understand the basic mechanisms of ischemia-induced tissue damage for developing therapies to reduce the destructive health and economic cost exposed by disorders characterized with reduced organ-specific blood flow (1). Reperfusion injury has caused the tissue damage which occurred via blood supply return to the tissue after a period of ischemia or lack of oxygen. The absence of nutrients and oxygen from blood causes restoration of circulation leading to inflammation and oxidative damage through the induction of oxidative stress rather than restoration of normal function during the ischemic period. Renal ischemia/reperfusion (IR) injury has a role in different clinical situations such as par-

${ }^{1}$ Department of Medical Biochemistry, Gazi University Faculty of Medicine, Ankara, Turkey, ${ }^{2}$ Department of Medical Genetics, Düzce University Faculty of Medicine, Düzce, Turkey, ${ }^{3}$ Department of Anatomy, Erciyes University Faculty of Medicine, Kayseri, Turkey, and ${ }^{4}$ Department of Pathology, Düzce University Faculty of Medicine, Düzce, Turkey

Address for correspondence: M. Nisari, Department of Anatomy, Erciyes Medical University, Talas Street, 38039, Kayseri, Turkey.

Phone: +90.352 .2076666 , Fax: +90.352 .4375285$ tial nephrectomy, renal transplantation, renal artery angioplasty, cardiopulmonary bypass, aortic aneurysm surgery, and elective urological operations. The temporary absence of renal blood supply may lead to tissue death. Additionally, reconstruction of blood flow to deprived tissue is also highly damaging (2-4). So exact understanding of the celular mechanisms occurring due to ischemia/reperfusion injury has great importance for to elimination of these negative effects.

The nucleoluses are important structures within cell nuclei. The synthesis, processing, and assemblance of ribosomal proteins of ribosomal RNAs occurr in the nucleolus. The nucleolus size and organization are directly associated with ribosome production and exhibite the functional compartmentalization of the nucleolar machinery.

Nucleolar-organizing regions (NORs) are site of the ribosomal genes located on chromosomes and composed of ribosomal DNA (rDNA) and proteins, some of them are argyrophilic. NORs are transcribed into ribosomal RNA that is processed to preribosomes in the nucleolus and becoming a part of mature ribosomes in the cytoplasm (5). When the NORs are active, they can be stained with silver. Silver binds with those transcriptionally active or transcribed and still retaining residual rRNA nonhistone-associated proteins. Bacause of the silver affinity, those proteins are named argyrophilic NOR (AgNOR)-associated proteins and silver staining method is the most reliable to show nucleoli in interphase nuclei (6). A lot 


\section{5-350}

of studies have been carried out about the importance of AgNOR proteins such as benign and malignant thyroid tissue (7-11), hair root cells of humans with alopecia or healthy individuals $(12$, 13), buccal epithelial cells of Down syndrome infants and healthy persons $(14,15)$, the effects of CO exposure on the NOR protein synthesis of hearth and lung cells (16-18) and so on. However, to our knowledge, there are no researches in the literature about the association between AgNOR proteins and renal ischemia/reperfusion (IR) injury. For this reason, we performed the study to show any possible effects of renal I/R injury on the NOR protein synthesis and possible association between the AgNOR proteins amount and histopathological injury score.

\section{Methods}

\section{Study design}

9 rats were randomly divided into 2 groups as $\operatorname{control}(\mathrm{C})(\mathrm{n}=$ $3)$ and ischemia/reperfusion $(I / R)(n=6)$. At the end of each in vivo study, the rats were euthanized under anesthesia and the kidneys were quickly removed, decapsulated and divided longitudinally into two equal sections. Each one was placed in 10\% formaldehyde solution. Ethical approval was taken from the local animal ethics committee according to accepted principles for laboratory animal use and care.

\section{Surgery and experimental protocol}

Nine Wistar-Albino female rats weighed between 200-250 g were included in the current study. The rats were anesthesized with an intraperitoneal injection of $80 \mathrm{mg} / \mathrm{kg}$ ketamine hydrochloride (Ketalar, Pfizer, Groton, CT) and $10 \mathrm{mg} / \mathrm{kg}$ xylazine hydrochloride (Rompun; Bayer, Leverkusen, Germany). The rats were placed on a thermal blanket to avoid hypothermia, and under the rib of left abdominal skin was shaved and washed using an antiseptic. The dorso-lateral incision $(2-3 \mathrm{~cm})$ was opened with sterile for- ceps and scalpel and both kidney and adipose tissue were taken out together via sterile scalpel. To induce ischemia, the left renal hilus was dissected and the left renal pedicle (artery and vein) was occluded for $45 \mathrm{~min}$. To help maintain the fluid balance during ischemia, $10 \mathrm{ml}$ of warm normal saline was instilled into the peritoneal cavity. When signs of emergence from anesthesia during surgery occured in the rats, they were anesthesized with an intraperitoneal injection of $40 \mathrm{mg} / \mathrm{kg}$ ketamine hydrochloride and anesthesia was allowed to continue. After the ischemic period, reperfusion was achieved by removal of the clamp and kidney was placed into the abdominal cavity with adipose tissue. Atraumatic needle (6-0 number Vicryl) was used to sew of the subcutaneous connective tissue and muscle layers. After the sewing procedure, the line of suture was washed with antiseptic.

\section{Experimental groups}

Control group $(\mathrm{C}: \mathrm{n}=3)$ : The Rats were not administered any $\operatorname{drug}(\mathrm{s})$ and ischemia/reperfusion procedure.

Ischemia/reperfusion group (I/R: $n=6)$ : The left renal vessels of the rats were occluded for $45 \mathrm{~min}$, followed by $24 \mathrm{~h}$ reperfusion, but the animals were not administered drug by intraperitoneal injection.

Rats were kept under an average ambient temperature of 27 ${ }^{\circ} \mathrm{C}$ under a $12 \mathrm{~h}: 12 \mathrm{~h}$ light : dark cycle.Also they were fed on a standard rodent diet and filtered tap water.

\section{Histopathological evaluation}

For histopathological injury score, the kidney tissues were dissected (approximately $1 \times 1 \times 1 \mathrm{~cm} 3$ in size). After routine histological follow-ups, the tissue samples fixed in $10 \%$ buffered formaldehyde for $24 \mathrm{~h}$, processed using agraded ethanol, xylene and embedded in paraffin. The paraffin sections were cut into 4 $\mu \mathrm{m}$ thick slices and stained with hematoxylin and eosin (HE) and PAS staining to evaluate a morphological overview of the tissue
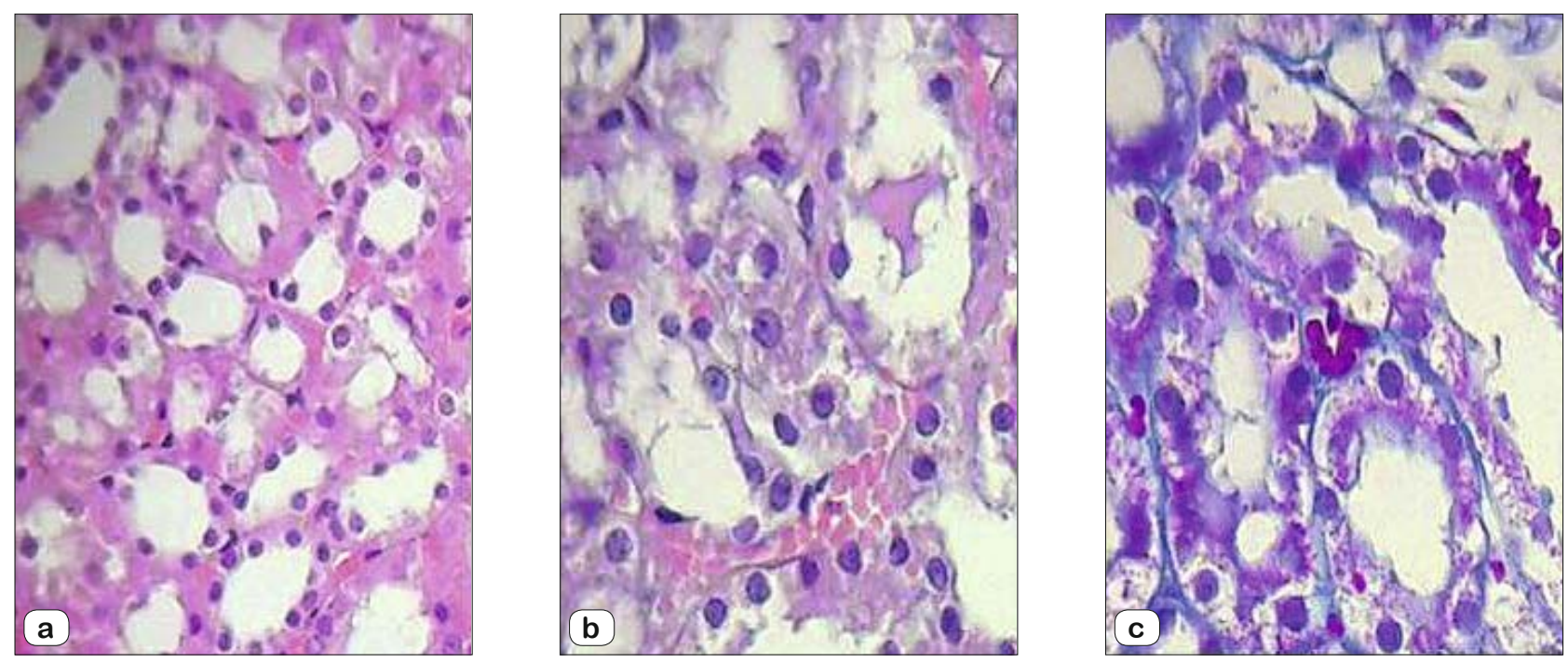

Fig. 1. Demostrative examples of the (HE) ( $a$ and $b$ ) and PAS (c) staining of kidney cells ( $a$ - control; $b$ and $c-I / R$ group). 


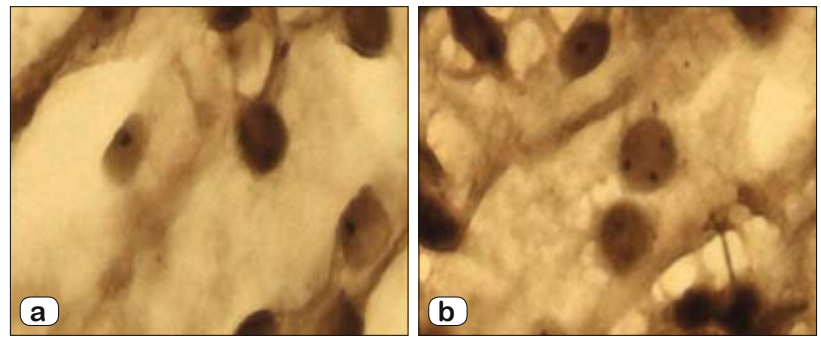

Fig. 2. Demostrative examples of the AgNOR staining of tubular epithelial cells of kidney ( $\mathrm{a}$ - control; $\mathrm{b}-\mathrm{I} / \mathrm{R}$ group).

and its structure. For light microscopic examination the pictures of the kidney' cells were photographed with Nikon light microscope (Nikon Eclipse i80, Tokyo, Japan), with an attached photographic machine (Nikon DS-Fi1).Each specimen was scored as to be taken into consideration for the degree of severity of histopathological changes as follows: hemorrhagia $(+1)$; necrosis of tubular epithelial cells $(+1)$; brush border(striated border or brush border membrane) loss $(+1)$; necrotic cells in tubular lumen of kidney tissue $(+1)$. Each kidney slide was evaluated and the severity of observed changes was scored using a scale of none (0), mild (1), moderate (2), and severe (3) damage. Histopathological analyses was made by an experienced pathologist. Demostrative examples of the histopathological changes are shown in Figure 1.

\section{AgNOR detection}

The obtained kidney tissue of the animals was dissected (approximately $1 \times 1 \times 1 \mathrm{~cm}^{3}$ in size). After routine histological fol- low up, the kidney tissue was cut to 4-mm thick sections and deparaffinized in xylene and then rehydrated in graded alcohol solutions before AgNOR staining. The slides were air-dried for $15 \mathrm{~min}$ at room temperature and fixed in fixative $(3: 1$ ratio of methanol and acetic acid solution) for $5 \mathrm{~min}$. AgNOR staining method was carried out according to the Benn and Perle protocol and the Lindner protocol, with a slight modification for all slides of groups $(19,20)$. The AgNOR staining tubular epithelial cells of kidney were viewed using a light microscope (Eclipse 80i, Nikon) and photographed via a digital camera (DigitalSight DSfil, Nikon). The captured images of tubular epithelial cells were transferred to image processing software (ImageJ version $1.47 \mathrm{t}$, National Institutes of Health, Bethesda, Maryland, USA). Fifty nuclei per slides were evaluated and the total AgNOR area per nuclear area (TAA/NA) and mean AgNOR number were detected via the "freehand selections" tool for each nucleus. Demostrative examples of the AgNOR staining tubular epithelial cells of kidney are shown in Figure 2.

Statistical analysis was performed using Statistical Package for Social Sciences (SPSS, Inc., Chicago, Illinois, USA) for Windows 17.0. The descriptive statistical methods (mean and standard deviation (SD)) and Mann-Whitney U tests were used to compare conrol and I/R groups. Statistical correlation between histopathological injury scores and both mean AgNOR numbers and the TAA/NA ratio in interphase nuclei of tubular epithelial cells of kidney were performed using Spearman correlation test. Results were given as mean $\pm \mathrm{SD}$, and $\mathrm{p}<0.05$ was accepted as statistically significant.

Tab. 1. Histopathological injury scores in the study.

\begin{tabular}{|c|c|c|c|c|c|c|}
\hline Groups & Hemorrhagia & $\begin{array}{c}\text { Necrosis of tubular } \\
\text { epithelial cells }\end{array}$ & $\begin{array}{l}\text { Brush border } \\
\text { membrane loss }\end{array}$ & $\begin{array}{l}\text { Necrotic cells in tubular } \\
\text { lumen of kidney tissue }\end{array}$ & Total Score & $\mathrm{p}$ \\
\hline$\overline{\mathrm{C} 1}$ & 0 & 0 & 0 & 0 & 0 & \multirow{9}{*}{0.016} \\
\hline$\overline{\mathrm{C} 2}$ & 0 & 0 & 0 & 0 & 0 & \\
\hline$\overline{\mathrm{C} 3}$ & 0 & 0 & 0 & 0 & 0 & \\
\hline$\overline{\mathrm{I} / \mathrm{R} 1}$ & 2 & 2 & 2 & 3 & 9 & \\
\hline $\mathrm{I} / \mathrm{R} 2$ & 1 & 2 & 2 & 2 & 7 & \\
\hline$\overline{\mathrm{I} / \mathrm{R} 3}$ & 3 & 2 & 1 & 1 & 7 & \\
\hline$\overline{\mathrm{I} / \mathrm{R} 4}$ & 1 & 2 & 2 & 2 & 7 & \\
\hline$\overline{\mathrm{I} / \mathrm{R} 5}$ & 3 & 2 & 2 & 2 & 9 & \\
\hline$\overline{\mathrm{I} / \mathrm{R} 6}$ & 2 & 2 & 2 & 2 & 8 & \\
\hline
\end{tabular}

Tab. 2. Mean AgNOR number and TAA/NA of groups.

\begin{tabular}{|c|c|c|c|c|c|c|}
\hline Groups & $\begin{array}{l}\text { Mean AgNOR Number } \\
\qquad(\mathrm{n}=50)\end{array}$ & $\begin{array}{c}\text { Mean TAA/NA } \\
(n=50)\end{array}$ & $\begin{array}{l}\text { Mean Value of Group for } \\
\text { AgNOR number }(n=150 \\
\text { for C; } n=300 \text { for } I / R)\end{array}$ & $\begin{array}{l}\text { Mean Value of Group for } \\
\text { TAA/NA }(n=150 \text { for } C ; \\
n=300 \text { for } \mathrm{I} / \mathrm{R})\end{array}$ & $\mathrm{Z}$ value & P Value \\
\hline $\mathrm{C} 1$ & $1.12 \pm 0.329$ & $0.023 \pm 0.011$ & \multirow{3}{*}{$1.177 \pm 0.379$} & \multirow{3}{*}{$0.023 \pm 0.011$} & \multirow{3}{*}{$-3.615^{\&}$} & \multirow{3}{*}{$0.000^{\&}$} \\
\hline $\mathrm{C} 2$ & $1.2 \pm 0.404$ & $0.024 \pm 0.010$ & & & & \\
\hline $\mathrm{C} 3$ & $1.21 \pm 0.404$ & $0.022 \pm 0.011$ & & & & \\
\hline $\mathrm{I} / \mathrm{R} 1$ & $1.26 \pm 0.599$ & $0.044 \pm 0.014$ & \multirow{6}{*}{$1.413 \pm 0.568$} & \multirow{6}{*}{$0.07 \pm 0.04$} & \multirow{6}{*}{$-15.174 *$} & \multirow{6}{*}{$0.000 *$} \\
\hline $\mathrm{I} / \mathrm{R} 2$ & $1.3 \pm 0.051$ & $0.057 \pm 0.047$ & & & & \\
\hline $\mathrm{I} / \mathrm{R} 3$ & $1.3 \pm 0.580$ & $0.061 \pm 0.028$ & & & & \\
\hline $\mathrm{I} / \mathrm{R} 4$ & $1.5 \pm 0.707$ & $0.069 \pm 0.033$ & & & & \\
\hline I/R5 & $1.44 \pm 0.705$ & $0.090 \pm 0.043$ & & & & \\
\hline I/R6 & $1.68 \pm 0.768$ & $0.099 \pm 0.074$ & & & & \\
\hline
\end{tabular}




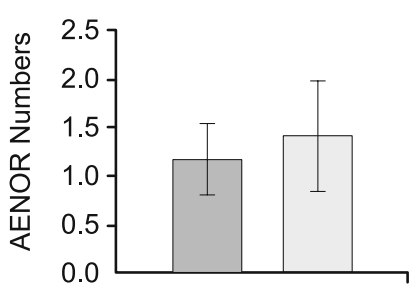

Groups

$\square$ Control group

I/R group

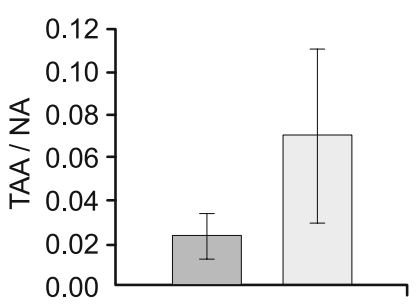

Groups

Control group

$\square$ I/R group

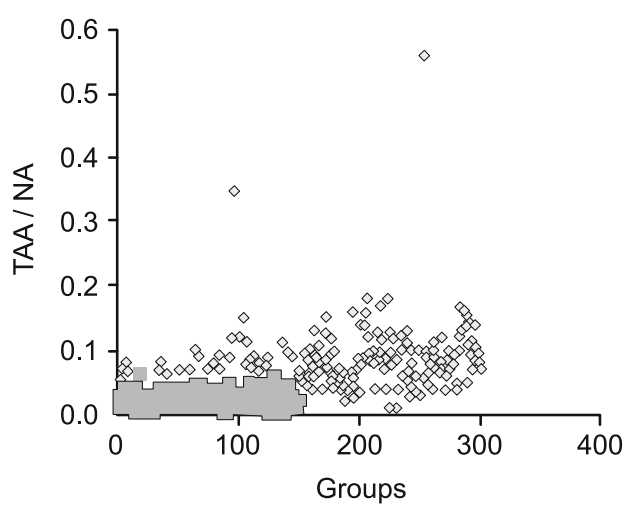

$\square$ Control group

$\diamond$ I/R group

Fig. 3. Comparison of control group and I/R group for mean AgNOR number and TAA/NA ratio.

\section{Results}

Hemorrhagia $(+1)$; necrosis of tubular epithelial cells $(+1)$; brush border (striated border or brush border membrane) loss $(+1)$; necrotic cells in tubular lumen of kidney tissue were evaluated during histopathological examination. Histopathological findings of the study are shown in Table 1. Significant differences between control and I/R groups were found for histopathological injury scores $(Z=-2.416, p=0.016)$.

Also, the differences between control group $(1.177 \pm 0.379)$ and $\mathrm{I} / \mathrm{R}$ group $(1.413 \pm 0.568)$ were significant for mean AgNOR number $(\mathrm{Z}=-3.615$ and $\mathrm{p}=0.000)$. Additionally, the differences between control group $(0.023 \pm 0.011)$ and $\mathrm{I} / \mathrm{R}$ group $(0.07 \pm 0.04)$ were significant for TAA/NA ratio $(Z=-15.174$ and $p=0.000)$ (Tab. 2, Fig. 3).

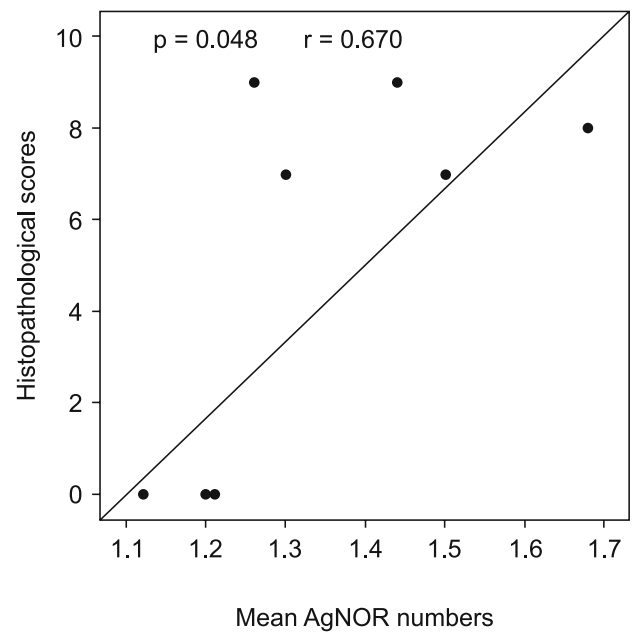

Additionally, there was a strong positive correlation betweenTAA/NA ratio and histopathological injury score $(r=0.728 ; \mathrm{p}=$ 0.026). Additionally, a strong positive correlation between AgNOR number per cell and histopathological injury score $(r=0.670 ; p=$ 0.048) was found (Fig. 4).

\section{Discussion}

$\mathrm{I} / \mathrm{R}$ injury is a complex event that is frequently seen in vascular surgery, organ procurement and transplantation, and can cause functional and structural cell damage. Hypoxia and acidosis are most often occuring damages during the ischemic period. Reactive oxygen species occur and neurtophils are activated during this period (21).

It was known that the nucleolus is related with the maintenance and regulation of important cellular processes such as ribosome

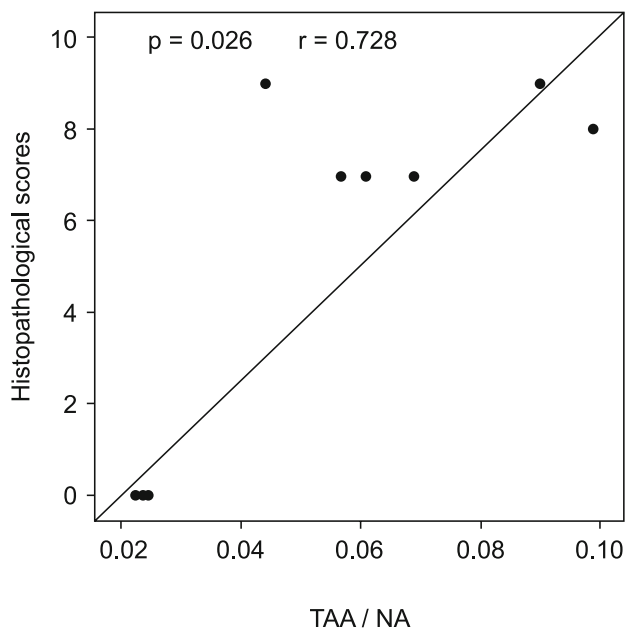

Fig. 4. Correlation between both AgNOR number per cell, TAA/NA and histopathological injury score. 
assembly, mitosis, the generation of ribonucleoprotein complexes and stress response (22). NORs are surrounded by a great number of regulatory proteins in interphase and they are functional subunits of the nucleolus (23). We reported that the AgNOR protein amount increased depending on the increase of $\mathrm{CO}$ exposure (also it caused hypoxic condition) in the lung and heart cells in our previous studies (16-18). In our current study, the TAA/NA ratio and total AgNOR number per total nuclear number increased depending on the I/R injury in the tubular cells of kidney, too. To the best of our knowledge, this is the first study evaluating and correlating AgNOR amounts with histopathological injury scores in rat kidneys exposed to $\mathrm{I} / \mathrm{R}$ injury.

IR injury can lead to acute kidney injury in different clinical settings including renal transplantation and hypovolemic and/ or septic shock. It was known that short periods of intermittent ischemia and reperfusion can trigger ischemic conditioning that is an inherent piece of the renal defense mechanism against ischemia. So a great number of studies are necessary to understand the signalling transduction pathways of renal ischemic conditioning (24).

All living cells tend to protect their structural and metabolic situation toward dangerous agents such as I/R injury. The current study showed that the expression capacity of rRNA gene, as detected via total TAA/NA and/or AgNOR number per total nuclear number, increased depending on the I/R injury in the kidney cells. Perhaps the AgNOR proteins may occur against I/R injury (Against endogenous and exogenous oxidative stress) and/or trigger the synthesis of some other proteins, which have protective features or roles in the signaling transduction pathways and gene expression regulation of renal ischemic conditioning. When the I/R injury duration is increased (longer than $45 \mathrm{~min}$ ), changes may occur in the AgNOR proteins amounts. To obtain more certain knowledge about the current topic, additional studies should be carried out. In this manner, new therapeutic approaches may be developed in the treatment of I/R injury in the future.

Significant correlations were found between the results of the histopathological injury score and both the mean AgNOR number and TAA/NA. The results of the histopathological injury score can be obtained with the evaluation of hemorrhagia, necrosis of tubular epithelial cells, brush border (striated border or brush border membrane) loss and necrotic cells in tubular lumen of kidney tissue. Thus, it may be said that only the detection of AgNOR protein synthesis amounts maybe used to obtain knowledge about the damaging degreeof the kidneys' cells, instead of the histopathological injury score requiring an experienced pathologist. The limitations of the current study is the relatively small number of groups. Our technique that was used for the detection of AgNOR proteins amounts, both the NOR area and nuclear area (NA) were used for the calculation of the TAA/NA proportion. Thus, more certain knowledge about cellular activities (proliferation, differentiation, and secretory activities etc.) of each cell could be obtained. Thus, indirect knowledge may be acquired about the behavior of the kidney cells for protection against $\mathrm{I} / \mathrm{R}$ injury. In addition to this, this technique provides simple, cheap, reliable and a valuable marker to evaluate the ribosomal gene activity in different metabolic states of cells, it has important advantages.

In conclusion, it was detected that the AgNOR protein levels increase depending on I/R injury. Also there was a significant correlation between histopathological injury scores and AgNOR protein amounts. Therefore, it may be said that the detection of these proteins amount may be used as an indicator to obtain a more exact knowledge about the cellular behaviour (self-protective mechanism of tubular epithelial cells) against I/R injury and celular damage levels instead of histopathological injury scores. Additional studies including large sample series should be performed to obtain more reliable knowledge about this topic. In this way, new therapeutic approaches for I/R injury may be developed.

\section{References}

1. O'Donnell CJ, Nabel EG. Genomics of cardiovascular disease. Genomics of cardiovascular disease. N Engl J Med 2011; 365: 2098-2109.

2. Conesa LE, Valero F, Nadal JC et al. N-acetyl-L-cysteine improves renal medullary hypoperfusion in acute renal failure. Am J Physiol 2001; 281: 730-773.

3. Reiter RJ. Oxidative processes and antioxidant defense mechanisms in the aging brain. FASEB J 1995; 9: 526-533.

4. Kurcer Z, Oguz E, Özbilge H, Baba F, Aksoy N, Çelik H et al. Melatonin protects from ischemia/reperfusion-induced renal injury in rats: this effect is not mediated by proinflammatory cytokines. J Pineal Res 2007; 43: $172-178$.

5. Hernandez-Verdun D. The nucleolus: a model for theorganization of nuclear functions. Histochem Cell Biol 2006; 126: 135-148.

6. Trere D. AgNOR staining and quantification. Micron 2000; 31: 127-131.

7. R. Eroz, N. Cucer, Z. Karaca, K. Unluhizarci, F. Ozturk. The Evaluation of Argyrophilic Nucleolar Organizing Region Proteins in Fine-Needle Aspiration Samples of Thyroid. Endocr Pathol 2011; 74-78.

8. R. Eroz, K. Unluhizarci, N. Cucer, F. Ozturk. The Value Of Argyrophilic Nucleolar Organising Region Protein Determinations in Non-Diagnostic Fine Needle Aspiration Samples (Due To Insufficient Cell Groups) Of Thyroid Nodules. Analyt Quant Cytol Histol 2013a; 226-232.

9. Eroz R, Cucer N, Unluhizarci K, Ozturk F. Detection and comparison of cut-off values for total AgNOR area/nuclear area and AgNOR number/ nucleus in benign thyroid nodules and normal thyroid tissue. Cell Biol Int 2013b; 37 (3): 257-261.

10. Eröz R, Ünlühizarci K, Cücer N, Baltaci D, Oktay M. Kistik Nodüler Guatirli Olgularin Tiroid Hücrelerindeki AgNOR Sayisi ve AgNOR Yüzey Alani/Çekirdek Alani Oraninin Yaş ve Cinsiyete göre Karşilaştirilmasi. Konuralp Tip Dergisi 2012a; 31-35.

11. Oktay M, Eroz R, Oktay NA, Erdem H, Başar F, Akyol L, Cucer N, Bahadir A. Argyrophilic nucleolar organizing region associated protein synthesis for cytologic discrimination of follicular thyroid lesions. Biotech Histochem 2015; 179-183.

12. Eroz R, Tasdemir S, Dogan H. Is there any relationship between decreased AgNOR protein synthesis and human hair loosing. Biotech Histochem 2012b; 494-498.

13. Eroz R, Yilmaz S, Cucer N. Argyrophilic nucleolar organizing region associated protein synthesis in hair root cells of humans at different developmental stages and sex Biotech Histochem 2013c; 267-271. 


\section{5-350}

14. Eroz R, Okur M, Ozkan A, Berik O, Gunes C. Does higher NORs expression affect the developmental stages of down syndrome infants? Genetic Counseling 2012c; 249-253.

15. Selvi B, Demirtas H, Eroz R, Imamoglu N. Investigation of the agedependent AgNOR protein level in buccal epithelial cells of healty individuals. Aging Clin Exp Res 2015; 201-208.

16. Colakoglu S, Saritas A, Eroz R, Oktay M, Yaykasli KO, Akoz A, Kaya E, Kandis H. Is one-time carbon monoxide intoxication harmless? Evaluation by argyrophilic nucleolar-organizing regions staining method. Hum Exp Toxicol 2015; 24-31.

17. Kandis H, Afacan MA, Eroz R, Colakoglu S, Bayramoglu A, Oktay M, Saritas A, Colak S, Kaya M, Kara IH. Can argyrophilic nucleolar organizing region-associated protein amount be used for the detection of cardiac damage? Hum Exp Toxicol 2015; 1-9.

18. Saritas A, Gunes H, Colakoglu S, Eroz R, Akoz A, Oktay M, Buyukkaya A, Kandis H, Ozkan A. Are There Any Effects of Chronic Carbon Monoxide Exposure on Argyrophilic Nucleolar Organizing Region-Associated Protein Synthesis in Rat Myocardium? Hum Exp Toxicol 2015; 1-8.
19. Benn PA, Perle M. Chromosome staining and banding techniques. In: Rooney DE, Czepulskowski BH (Eds). Human cytogenetics: Constitutional analysis: A practical approach. London: Oxford University Press, 1986; 91-118.

20. Lindner LE. Improvements in the silver-staining technique for nucleolar organizer regions (AgNOR). J Histochem Cytochem 1993; 41 (3): 439-445.

21. Jaeschke $\mathbf{H}$. The inflammatory response after hepatic ischemia/reperfusion. In: Lemaster JJ, Oliver C (Eds).Cell Biology of Trauma. Florida: CRC Press, 1995, pp. 127-142.

22. Boisvert FM, van Koningsbruggen $\mathbf{S}$, Navascues $\mathbf{J}$ et al. The multifunctional nucleolus. Nat Rev Mol CellBiol 2007; 8: 574-585.

23. Ploton D, Menager M, Lechki $\mathbf{C}$ et al. Silver stainingof nucleolus organizer regions (NORs). Application tothe study of nucleolar structure and value in pathology. Ann Pathol 1988; 8: 248-252.

24. Kierulf-Lassen C, Nieuwenhuijs-Moeke GJ, Krogstrup NV, Oltean M, Jespersen B, Dor FJ. Molecular Mechanisms of Renal Ischemic Conditioning Strategies. Eur Surg Res 2015; 55 (3): 151-183.

Received November 24, 2015. Accepted December 4, 2015. 